\title{
VLIV ODPORU PŘI PŘESTUPU TEPLA NA NEJNIŽŠÍ VNITŘNÍ POVRCHOVOU TEPLOTU OKNA
}

\author{
EFFECT OF HEAT TRANSFER RESISTANCE ON THE LOWEST \\ INTERNAL WINDOW SURFACE TEMPERATURE
}

\author{
Petra Vorlíčková* ${ }^{*}$, Miloš Kalousek ${ }^{1}$
}

* vorlickova.p@fce.vutbr.cz

${ }^{1}$ Vysoké učení technické v Brně, Fakulta stavební, Ústav pozemního stavitelství, Veveři 331/95, 60200 Brno, Česká republika

\begin{abstract}
Abstrakt
Při posuzování nejnižší vnitřní povrchové teploty je dobré přihlédnout i $\mathrm{k}$ problematice proudění vzduchu v místnosti, což je zjednodušeně zakotveno ve formě odporu při přestupu tepla. Dané normové hodnoty se mohou ve skutečnosti měnit, a to má vliv na výsledné povrchové teploty. V práci je aplikována hliníková lišta jako vodivý materiál z interiérové strany na kritická místa detailu parapetu dřevěného okna a variován přitom odpor při přestupu tepla. Přesněji je řešena připojovací spára u zasklení $\mathrm{k}$ okennímu rámu a dále u rámu ke stěně. Sledujeme přitom chování lišty při různých tvarech a tloušt'kách materiálu a hloubce uložení rámu ve stěně a zasklení v rámu. Výsledky ukázaly, jak veliký vliv může odpor př̌i přestupu tepla na interiérové straně mít.
\end{abstract}

\section{Klíčová slova}

Odpor při přestupu tepla, tepelná vodivost, proudění vzduchu, povrchová kondenzace

\begin{abstract}
When assessing the lowest internal surface temperature, it is good to take into account the issue of air flow in the room, which is simply anchored in the form of resistance to heat transfer. The given standard values may in fact vary, and this affects the resulting surface temperatures. In this work, an aluminum strip is applied as a conductive material from the interior to critical points of detail of the window sill of a wooden window and the resistance to heat transfer varies. More precisely, the connection joint is solved for the glazing to the window frame and further for the frame to the wall. We monitor the behavior of the bar with different shapes and thicknesses of material and the depth of the frame in the wall and glazing in the frame. The results showed how much resistance the heat transfer resistance can have on the interior side.
\end{abstract}

Key words

Heat transfer resistance, thermal conductivity, air flow, surface condensation

\section{1 ÚVOD}

Veliký vliv na chování okna má proudění vzduchu. Tento jev byl normově zakotven ve formě odporu při přestupu tepla jak na straně interiérové, tak na straně exteriérové. V exteriéru je jasně uvažováno proudění vzduchu vlivem větru, ovšem na straně interiérové se tyto podmínky můžou měnit, například typem vytápění, umístěním radiátoru, velikostí parapetu, umístěním okna ve stěně. Těmito faktory, a i dalšími je ovlivněnou proudění teplého vzduchu kolem okna, především kolem oblasti parapetu.

Cílem práce je zkoumání vlivu hodnoty odporu při přestupu tepla na výsledné hodnoty nejnižší vnitřní povrchové teploty. Odpor při přestupu tepla vstupuje do všech tepelně-technických výpočtů při hodnocení konstrukcí. V následující práci byla hodnocena nejnižší vnitřní povrchová teplota při variování vybraných hodnot odporu při přestupu tepla na interiérové straně na detailu parapetu tak, aby byla vyloučena povrchová kondenzace v kritických oblastech. V našem př́ípadě se jedná o připojovací spáru zasklení na rám a uložení rámu ve stěně.

Modelován byl dřevěný okenní rám s izolačním dvojsklem osazený na zděné stěně tloušt'ky $60 \mathrm{~cm}$ bez a s aplikovanou hliníkovou lištou na interiérové straně. Tato lišta zvyšuje díky své vodivosti teplotu v kritické oblasti připojovací spáry a zlepšuje tak často nevyhovující stav nejjednodušší možnou cestou (bez výměny či bourání). Funkčnost lišty byla již ověřena $\mathrm{v}$ předchozích publikacích, vychází přitom z patentované technologie [1], [2]. 


\section{LITERÁRNÍ PŘEHLED}

Tato publikace navazuje na souběžně publikovaný článek "Eliminace povrchové kondenzace na zasklení a připojovací spáře dřevěného okna." Hliníková lišta zde byla modelována jako vodivý materiál umístěný na interiérové straně připojovací spáry parapetu a zasklení dřevěného okenního rámu. Lišta byla zkoušena $\mathrm{v}$ různých tloušt kách $(0,3 \mathrm{~mm}, 0,6 \mathrm{~mm}, 0,9 \mathrm{~mm})$ a tvarech (lišta zasahující svislou částí až na rám a lišta pouze vodorovná) a je prokázána její efektivnost při různém umístění rámu ve stěně (lišta na parapetu) a při různé hloubce zasklení v rámu (lišta na zasklení). $\mathrm{V}$ následujícím textu je rozebrána $\mathrm{k}$ této problematice variace odporu při přestupu tepla na jiné než normové hodnoty.

\section{Povrchová kondenzace}

Výplně otvorů $\mathrm{v}$ obvodových konstrukcích jsou jednou z nejslabších částí obálky budovy. Porucha vzniká především v místech napojení, tj. připojovací spára zasklení na rám a dále rám na stěnu. Zde může docházet k poklesu povrchové teploty až pod hodnotu rosného bodu a přebytečná vlhkost kondenzuje na povrchu.

Při pozorování této poruchy je zjevné, že se nejčastěji projevuje při spodním lící okna. Př́ícin může být více:

- $\quad$ proudění vzduchu v místnosti

Pokud bychom zkoumali proudění vzduchu, např́klad v počítačovém modelu, objevili bychom vzduchovou kapsu nad parapetem. Tento jev je způsoben např́klad širokými parapety, které můžou i zakrývat radiátor. Pokud bychom zůstali u radiátoru, původcem poruchy můžou být i zvlhčovače zavěšené prímo na radiátorech. Dále nemalou roli hrají stažené žaluzie nebo závěsy omezující proudění vzduchu [3].

- slabé sálání otopného systému

V případě podlahového vytápění mnohdy nedosahuje jeho výkon dostatečného sálání tepla. Podlahové vytápění totiž pracuje $\mathrm{s}$ větší plochou s menšími teplotami. V takových případech se doporučuje alespoň zhuštění hadů pod okny, a hlavně v místě otvorů neumístovat překážky [4], [5].

- proudění plynu mezi zasklením

Stejně jako v místnosti i mezi zasklením proudí vzduch. Teplý plyn ohřátý z interiéru stoupá nahoru, nahoře se opět $\mathrm{v}$ nejslabším místě ochladí a začne klesat podél exteriérové strany zasklení. Tento jev je výraznější u izolačních dvojskel než u trojskel. Dalším důležitým faktorem je typ distančního rámečku jako nejslabší části zasklení [4].

- Špatné tepelně technické vlastnosti rámu, zasklení a montáže

Především se jedná o počet izolačních skel (dvojsklo, trojsklo), druh rámu a stavební hloubka rámu, typ montáže (zapuštěná, předsazená, lícovaná) anebo např́ílad možnost zateplení rámu.

- vysoká relativní vlhkost $\mathrm{v}$ interiéru

$S$ příchodem těsných oken je omezena přirozená infiltrace vzduchu a je nutné důsledně větrat. Např́ílad v noci dochází $\mathrm{k}$ poklesu teploty a zvyšuje se tak relativní vlhkost vzduchu v interiéru. Z tohoto důvodu se povrchová kondenzace objevuje nejčastěji v noci/nad ránem. [3].

- hloubka zapuštění rámu v ostění

Při hodnocení detailů se snažíme eliminovat zalomení, př́ípadně úplné přerušení izoterm. Hloubka uložení rámu v ostění a s tím spojený i typ montáže má velký vliv na nejnižší vnitřní povrchovou teplotu na připojovací spáře a lineární činitel prostupu tepla. S větším vyložením rámu do exteriéru se z může zvětšovat vzduchová kapsa nad parapetem. Jak již bylo vysvětleno výše, v prostoru nad parapetem zůstává studený vzduch, na který nedosáhne teplý proudící vzduch z radiátoru např́ílad přes široký parapet.

- hloubka zapuštění zasklení v rámu

Distanční rámeček spojující skleněné tabule je vždy slabým místem izolačního zasklení. Vymezuje vzdálenost skel a zároveň těsní vzduchovou mezeru mezi skly. Dủležité je, aby izolační plyn neunikal ven a vlhkost nevnikala dovnitř, čehož je docíleno např́ílad díky butylu u teplého distančního rámečku. Ovšem stále je tepelným mostem po obvodu skla. To je jeden z důvodů, proč se jeho vývoj neustále zlepšuje [6].

Předpoklad je takový, že s větší hloubkou zapuštění zasklení stoupá nejnižší vnitřní povrchová teplota na připojovací spáře zasklení. Ovšem estetická hodnota s větší hloubkou zasklení v rámu klesá a je potřeba hledat kompromis mezi těmito kritérii. 
- vnější zateplení rámu

Ke zvýšení nejnižší vnitřní povrchové teploty může pomoci při výměně oken vnější zateplení rámu. Dnes nejlépe hodnocené systémy předsazené montáže do izolačních profilů je drahá záležitost a je nutné posoudit i její ekonomickou výhodnost. Vedle vyšší pořizovací ceny má vliv na návratnost investice např́klad vodivost nosné konstrukce, ceny energií anebo nadmořská výška stavby. [7]. Kladem této možnosti je eliminace lineárního činitele prostupu tepla, ovšem zde opět zvětšujeme velikost parapetu na interiérové straně a tím může nastat zhoršené proudění vzduchu.

- $\quad$ orientace ke světovým stranám

Dispozice objekti̊ je velkou mírou ovlivněna orientací ke světovým stranám. Vedle posouzení osvětlení a proslunění obytných místností se jedná i o získání maximálních tepelných zisků v zimním období (samozřejmě za splnění podmínky eliminace přehřívání v období letním). Na severní stranu nedopadají sluneční paprsky, a proto je potřeba uvažovat s chladnější stěnou a umist'ovat sem nejméně oken.

- Porušení tmelu v uložení

Např́iklad u velkých skel tmelených až na místě hrozí prohnutí vlivem vlastní váhy a tím porušení tmelu v uložení. Tento problém nastává spíše u ostění [8].

\section{Vliv odporu při přestupu tepla}

Odpor při přestupu tepla $R_{s i}$ označuje jakousi mezní vzduchovou vrstvu přiléhající ke konstrukci, která je na styku se vzduchem. Tato veličina zohledňuje vliv proudění vzduchu a sálavé výměny tepla jak v interiéru, tak v exteriéru. V exteriéru je dle normy ČSN 73 0540-3 zavedena hodnota $0,04 \mathrm{~m}^{2} \mathrm{~K} / \mathrm{W}$ pro všechny směry tepelných toků. $\mathrm{V}$ interiéru je hodnoty mírně rozcházejí. Pro svislý tepelný tok vzhůru platí hodnota $0,10 \mathrm{~m}^{2} \mathrm{~K} / \mathrm{W}$, pro tepelný tok dolů $0,17 \mathrm{~m}^{2} \mathrm{~K} / \mathrm{W}$ a pro vodorovný tepelný tok $0,13 \mathrm{~m}^{2} \mathrm{~K} / \mathrm{W}$ [9], [10].

Pro výpočet povrchových teplot (příp. teplotního faktoru vnitřního povrchu) je dle ČSN EN ISO 13788 pro neprůsvitné konstrukce zavedena hodnota tepelného odporu při přestupu na straně interiéru $0,25 \mathrm{~m}^{2} \mathrm{~K} / \mathrm{W}$. U oken zůstává v platnosti hodnota $0,13 \mathrm{~m}^{2} \mathrm{~K} / \mathrm{W}[11]$.

Výše uvedený výčet hodnot odporu při přestupu tepla představuje poměrně veliký rozptyl, což může mít vliv na výsledné povrchové teploty oproti skutečnému chování mezní vrstvy ve stavbě vlivem užívání nebo například umístěním nábytku.

\section{METODIKA}

Detaily byly hodnoceny z hlediska nejnižší vnitřní povrchové teploty dle ČSN 73 0540-2 po přepočtu z teplotního faktoru vnitřního povrchu [12]. V př́ípadě nevyhovujícího stavu byla lepena hliníková lišta na připojovací spáru zasklení a na rám okna. Díky své vysoké vodivosti lišta přivede při styku s vnitřním vzduchem teplo do kritického místa na připojovací spáře a zamezí tak vzniku povrchové kondenzace. Při sledování tohoto jevu využíváme patentované technologie.

Při modelování sledujeme množství tepla, jaké si dokáže materiál předat s okolním prostředím, tj. teplo z interiéru a případně chlad z rámu. Hliníkový plech je tvarovatelný tak, aby maximálně kopíroval tvar okna a barvený, díky čemuž nepůsobí rušivě, jak by se dalo očekávat.

Lišta byla vždy variována ve třech tloušt'kách $(0,3 \mathrm{~mm}, 0,6 \mathrm{~mm}$ a $0,9 \mathrm{~mm})$. V př́ipadě aplikace lišty na zasklení byla navíc experimentálně měněna hloubka zapuštění zasklení v rámu. U lišty na připojovací spáře parapetu byla zkoušena lišta ve dvou tvarových provedeních. S přesahem na rám a pouze vodorovná lišta, přičemž byla vždy lišta modelována podél celé hloubky parapetu. V tomto případě byla měněna hloubka uložení rámu ve stěně pro srovnání chování lišty v jiných počátečních podmínkách.

Veškeré modelování proběhlo v programu Ansys metodou konečných prvků. Okrajové podmínky výpočtu byly voleny pro exteriér $-15^{\circ} \mathrm{C}$ s hodnotou odporu při přestupu tepla $0,04 \mathrm{~m}^{2} \mathrm{~K} / \mathrm{W}$ a pro interiér $21^{\circ} \mathrm{C} \mathrm{s}$ hodnotami odporu při přestupu tepla $0,05 \mathrm{~m}^{2} \mathrm{~K} / \mathrm{W}$, dále $0,10 \mathrm{~m}^{2} \mathrm{~K} / \mathrm{W}$ až po $0,15 \mathrm{~m}^{2} \mathrm{~K} / \mathrm{W}$. Veškeré výpočty byly provedeny v programu Ansys metodou konečných prvků. 


\section{VÝSLEDKY}

V následujícím vyhodnocení byl modelován detail parapetu u zděné stěny tl. $60 \mathrm{~cm}$ s dřevěným okem osazeným izolačním dvojsklem s teplým distančním rámečkem. Na zasklení i rám okna byla vždy aplikována lišta ve třech tloušt'kách a s třemi hodnotami odporu při přestupu tepla na interiérové straně uvažovanými jak na okně, tak na části parapetu a stěně.

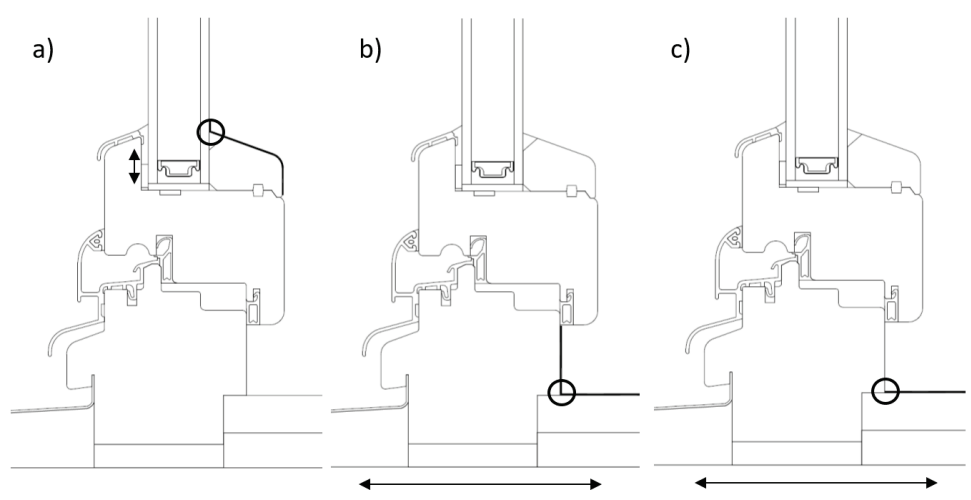

Obr. 1 Schéma dřevěného okenního rámu s označením sledovaného místa a) s hliníkovou lištou aplikovanou na zasklení, b) s hliníkovou lištou umístěnou na parapetu s přesahem na rám okna, c) s hliníkovou lištou umístěnou na parapetu jen vodorovně.

\section{Vliv odporu při přestupu tepla lišty na zasklení}

V následujícím grafu můžeme sledovat závislost hloubky distančního rámečku v rámu na teplotě na zasklení (viz. Obr. 1). Pro hodnocení byla vybrána lišta o rozvinuté délce $50 \mathrm{~mm}$, z toho 5 milimetrů svisle na zasklení.
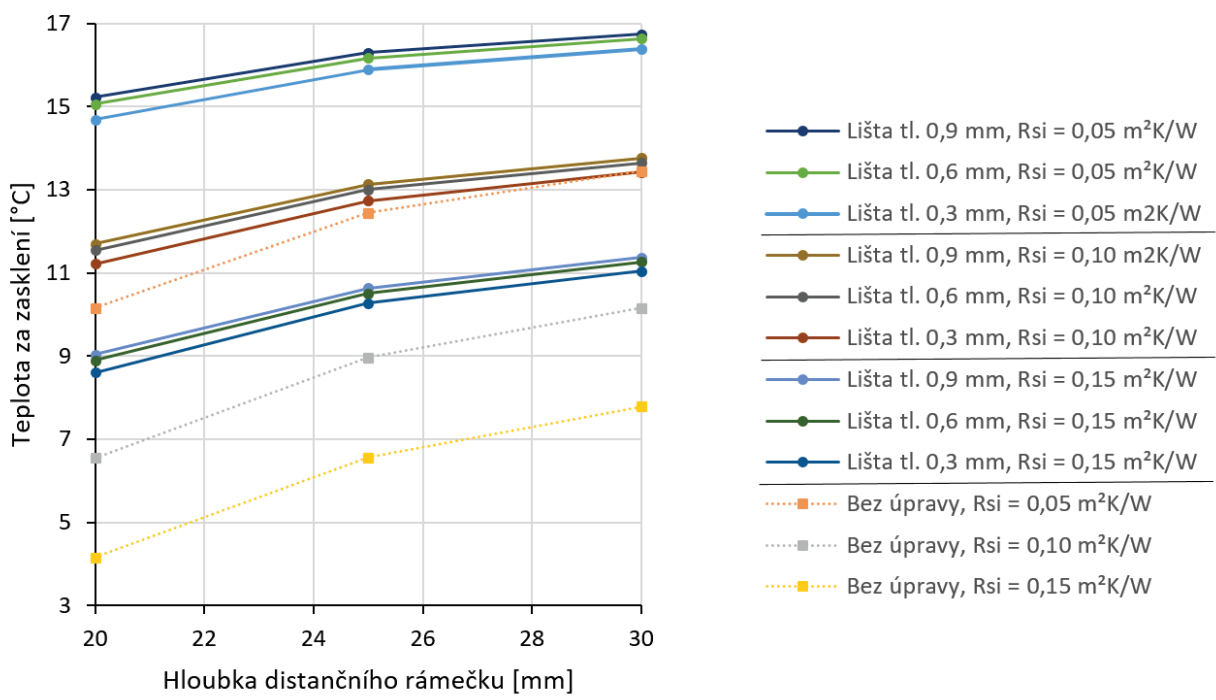

Obr. 2 Graf závislosti teploty na zasklení na hloubce zapuštění zasklení pro dřevěný okenní rám s hliníkovou lištou na okenním zasklení. 


\section{Vliv odporu při přestupu tepla lišty na parapetu}

Druhá část posouzení se věnuje liště aplikované na parapetu. Byly zkoušeny dvě varianty tvaru lišty. První se svislým přesahem na rám okna, druhá pouze vodorovná. Na grafu níže můžeme vidět závislost umístění rámu ve stěně (měřeno od interiéru) na teplotě na připojovací spáře (viz. Obr. 2).
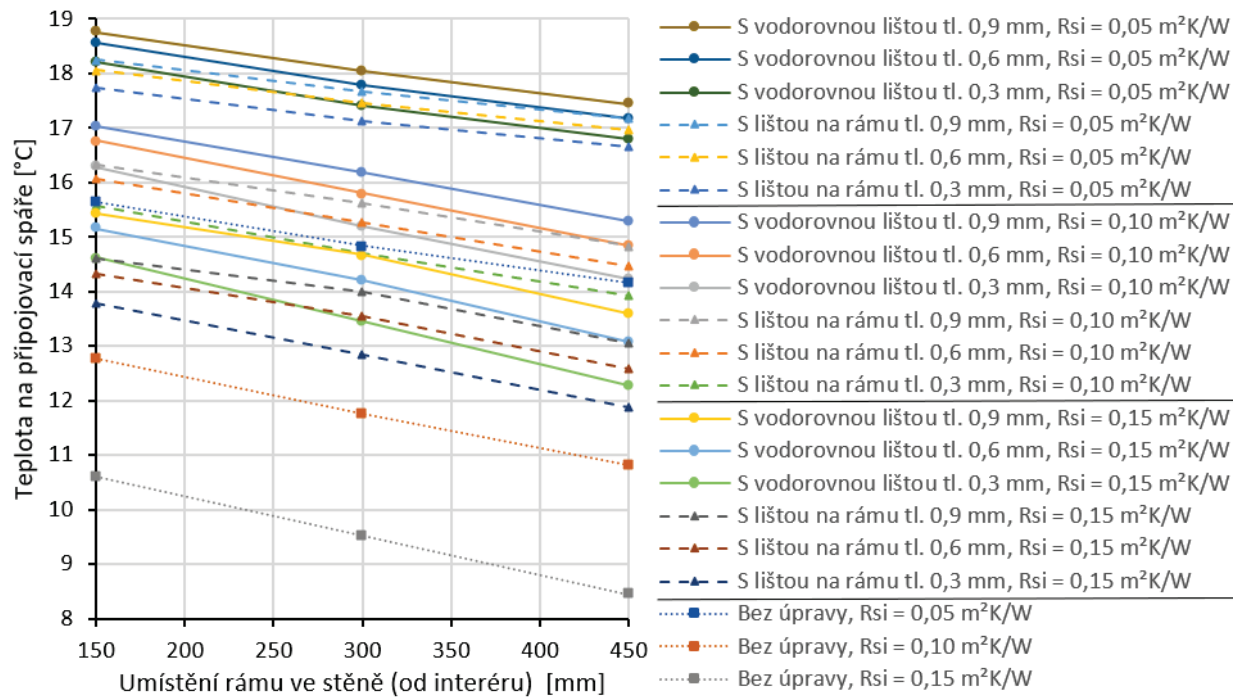

Obr. 3 Graf závislosti teploty na připojovací spáře na hloubce umístění rámu ve stěně pro dřevěný okenní rám s hliníkovou lištou na připojovací spáře parapetu.

\section{DISKUZE}

Ve všech případech došlo k nárůstu nejnižší vnitřní povrchové teploty po aplikaci lišty, dalšího zlepšení bylo dosaženo variací odporu při přestupu tepla. Obecně nejlepších výsledků bylo dosaženo při uvažování hodnoty odporu při přestupu tepla $0,05 \mathrm{~m}^{2} \mathrm{~K} / \mathrm{W}$, tj. při zajištění intenzivního proudění vzduchu kolem rámu. $\mathrm{Z}$ výsledů je vidět, jak veliký vliv na nejnižší vnitřní povrchovou teplotu má vliv proudění vzduchu, který jak víme může být velmi proměnlivý.

Pro obě hodnocení platí, že nejlepších výsledků dosáhla lišta tloušt'ky $0,9 \mathrm{~mm}$. Při variování odporu při přestupu tepla se ukázaly změny $\mathrm{v}$ teplotách konstantní.

Výsledky pro normové hodnoty odporu při přestupu tepla jsou k vidění v souběžně publikovaném článku "Eliminace povrchové kondenzace na zasklení a připojovací spáře dřevěného okna."

\section{Vliv odporu při přestupu tepla lišty na zasklení}

$\mathrm{V}$ př́ípadě aplikace lišty na zasklení bylo dosaženo nejvyššího nárůstu teplot pro $\mathrm{R}_{\mathrm{si}}=0,10 \mathrm{~m}^{2} \mathrm{~K} / \mathrm{W}$ u modelované hloubky zapuštění distančního rámečku $25 \mathrm{~mm}$, přesněji činí rozdíl teplot $5,15^{\circ} \mathrm{C}$ (rozdíl pro jednu variantu odporu při přestupu tepla s a bez lišty).

Mezi odlehlými hodnotami odporu při přestupu tepla na zasklení $\left(0,05 \mathrm{~m}^{2} \mathrm{~K} / \mathrm{W}\right.$ a $\left.0,15 \mathrm{~m}{ }^{2} \mathrm{~K} / \mathrm{W}\right)$ došlo $\mathrm{k}$ nejvyššímu teplotnímu rozdílu $6{ }^{\circ} \mathrm{C}$ pro variantu detailu bez úpravy s hloubkou distančního rámečku $20 \mathrm{~mm}$.

\section{Vliv odporu při přestupu tepla lišty na parapetu}

V místě parapetu vychází nejlépe vodorovná lišta, přitom směrem k exteriéru klesá její účinnost, ale stále se jeví jako nejvýhodnější. U vodorovné lišty, která se neochlazuje od rámu okna, došlo k nejvyššímu nárůstu teplot po aplikaci lišty pro $\mathrm{R}_{\mathrm{si}}=0,15 \mathrm{~m}^{2} \mathrm{~K} / \mathrm{W}$ v prŕípadě montáže nejdále do exteriéru (hloubka zapuštění $450 \mathrm{~mm}$ ), kdy maximální rozdíl teplot činí $5,15^{\circ} \mathrm{C}$. 
Mezi hodnotami odporu při přestupu tepla $\left(0,05 \mathrm{~m}^{2} \mathrm{~K} / \mathrm{W}\right.$ a $\left.0,15 \mathrm{~m}^{2} \mathrm{~K} / \mathrm{W}\right)$ byl naměřen největší teplotní rozdíl $5,71^{\circ} \mathrm{C}$ pro exteriérovou montáž okna (hloubka zapuštění $450 \mathrm{~mm}$ ) bez úpravy lištou.

\section{ZÁVĚR}

Cílem práce bylo zkoumání vlivu hodnoty odporu při přestupu tepla (proudění vzduchu v místnosti) na výsledné hodnoty nejnižší vnitřní povrchové teploty tak, aby byla vyloučena povrchová kondenzace na vybraném detailu parapetu.

Po aplikaci lišty byla zvýšena nejnižší vnitřní povrchová teplota v kritických místech detailu, tj. v místě připojovací spáry zasklení na rám a rámu na stěnu. Ukázalo se konstantní chování mezi tloušt'kami lišty a vlivem odporu tepla při přestupu. Nejlepších vlastností dosáhla lišta s tloušt'kou $0,9 \mathrm{~mm}$ a obecně nejvyšších teplot bylo dosaženo při uvažování odporu při přestupu tepla na celé interiérové straně $0,05 \mathrm{~m}^{2} \mathrm{~K} / \mathrm{W}$ (tato hodnota představuje intenzivní proudění vzduchu).

V místě parapetu byla ukázána jako nejvýhodnější lišta pouze vodorovná, lišta se svislým přesahem na rám okna je chladnějším povrchem ochlazována. Dle očekávání nastal rozdíl oproti normovým hodnotám uvedeným ve druhém článku "Eliminace povrchové kondenzace na zasklení a připojovací spáře dřevěného okna."

Odpor při přestupu tepla ovlivňuje proudění vzduchu, z tohoto důvodu je v exteriéru normově zakotvena nejnižší hodnota a v interiéru se hodnoty zvyšují až po posuzování povrchových teplot neprůsvitných konstrukcí, kde je hodnota nejvyšší. Rozptyl teplot při uvažování měnícího se odporu v mezní vzduchové vrstvě je pro jinak stejný detail až $6{ }^{\circ} \mathrm{C}$. Tento rozdíl teplot může určit, zdali bude docházet k povrchové kondenzaci či nikoliv.

Podnětem $\mathrm{k}$ dalšímu výzkumu může být modelování proudění vzduchu a sledování měnícího se odporu při přestupu tepla, s kterým jsou spojeny povrchové teploty a možná povrchová kondenzace. 3D model místnosti bude mnohem věrohodněji a přesněji vypovídat o skutečných hodnotách $R_{s i}$ a jejich př́ípadných změnách.

\section{Použité zdroje}

[1] VORLÍČKOVÁ, P.; KALOUSEK, M. Zamezení vzniku kondenzace na okenním zasklení a v připojovací spáře. In JUNIORSTAV 2021. 23. odborná konference doktorského studia s mezinárodní účastí. Brno: Vysoké učení technické v Brně, Fakulta stavební, 2021. s. 765-770. ISBN: 978-80-86433-75-2

[2] VORLÍČKOVÁ, P.; KALOUSEK, M. Možnosti zvýšení povrchové teploty nad rosný bod na připojovací spáře a zasklení okna. In JUNIORSTAV 2020. 22. odborná konference doktorského studia s mezinárodní účastí. Brno: Vysoké učení technické v Brně, Fakulta stavební, 2020. s. 918-924. ISBN: 978-80-86433-73-8.

[3] HORÁK, Vladimír. Kondenzace vlhkosti na oknech [online]. In: . Kroměříž, 2011. Dostupné z: http://www.portastyl.cz/soubor-kondenzace-vlhkosti-na-oknech-49-.pdf

[4] VELUX. Jak se bránit kondenzaci na oknech: Př́činy a náprava kondenzace [online]. In: . s. 9. Dostupné z: https://velcdn.azureedge.net/-/media/marketing/cz/katalogy/pdf/v-cz_brozura-kondenzace.pdf

[5] Podlahové vytápění nebo radiátory? Reacon corporation [online]. Dostupné z: https://reacon.cz/clanky/podlahove-vytapeni-nebo-radiatory/

[6] Distanční rámeček. Izoltechnik [online]. Dostupné z: https://www.izoltechnik.cz/produktyizoltechnik/plastova-okna/zaskleni/distancni-ramecek

[7] ŽIDEK, Ondřej. ŘEŠENÍ OSAZENÍ OKEN Z TEPELNĚ-TECHNICKÉHO A EKONOMICKÉHO POHLEDU. ATELIER DEK [online]

[8] VALEŠ, Radomil. PROBLEMATIKA KONDENZACE VLHKOSTI NA IZOLAČNÍM SKLE OKNA [online]. Dostupné z: https://www.kplasty.cz/w/kplasty/files/sklo_problematika_kondenzace_vlhkosti_na_izolacnim_skle_okna.pdf

[9] Odpor při přestupu tepla. TZB-info- [online]. Dostupné z: https://stavba.tzb-info.cz/prostup-teplastavebni-konstrukci/314-odpor-pri-prestupu-tepla

[10] TYWONIAK, Jan. Pozemní stavitelství VI: pro SPŠ stavební : stavební fyzika, zdravotní nezávadnost a požární bezpečnost staveb. Praha: Grada, 2014. Studium (Grada). ISBN 978-80-247-5102-3.

[11] ČSN EN ISO 13788 - Tepelně-vlhkostní chování stavebních konstrukcí a stavebních prvků - Vnitřní povrchová teplota pro vyloučení kritické povrchové vlhkosti a kondenzace uvnitř konstrukce Výpočtové metody. 2019.

[12] ČSN 73 0540-2:2011 Tepelná ochrana budov - Č́st 2: Požadavky. Z1. Praha: ÚNMZ, 2012. 